\title{
Biosynthesis of Green Silica Nanoparticles and Its Effect on Cotton Aphid, Aphis gossypii Glover and Mealybug, Phenacoccus solenopsis Tinsley
}

\author{
G. Pavitra $^{1 *}$, N. Sushila ${ }^{1}$, A.G. Sreenivas ${ }^{1}$, J. Ashok $^{1}$ and H. Sharanagouda ${ }^{2}$ \\ ${ }^{1}$ Department of Agricultural Entomology, College of Agriculture, UAS, Raichur, \\ Karnataka, India \\ ${ }^{2}$ Department of Processing and Food Engineering, CAE, UAS, Raichur, Karnataka, India \\ *Corresponding author
}

\section{A B S T R A C T}

\begin{tabular}{|l|}
\hline Ke y w o r d s \\
Rice husk, Silica \\
nanoparticles, Cotton, \\
Aphis gossypii, \\
Phenacoccus solenopsis
\end{tabular}

Keywords

Rice husk, Silica nanoparticles, Cotton, Phenacoccus solenopsi

Accepted: 12 September 2018 Available Online:
Sucking pests have become a serious problem in $B t$ cotton. The cotton aphid and mealybug reduces its yield to the extent of 30-40 per cent and 40-50 per cent, respectively. In this context an investigation was carried out on synthesis of silica nanoparticles from rice husk and its impact against cotton aphid and mealybug during 2017-18 at centre for nanotechnology lab, UAS Raichur. For comparison purposes, metal silica nanoparticles and dinotefuran 20\% SG was used as an insecticide. The biosynthesised nanoparticles were characterized by zetasizer (size: $26.19 \mathrm{~nm}$ ), UV-visible spectroscopy (wavelength: $310 \mathrm{~nm}$ ), X-ray diffraction (absorption at $2 \theta=15-25^{\circ}$ region) and scanning electron microscope (agglomerated form with spherical shape). At five days after treatment green silica nanoparticle at 2000 ppm caused cent per cent mortality of both cotton aphid and mealybug. Pesticidal activity of silica nanoparticles revealed that at $2000 \mathrm{ppm}$ concentration, maximum mortality of insects was recorded and hence can be selectively used for suppression of the pest.

\section{Introduction}

Cotton occupies 5\% of the total cropped area distributed among three different agroclimatic zones in India, and consumes 55\% pesticide share accounting for $40 \%$ of total production costs. This fact signifies the impact of insect pests and the increased agrochemical use in cotton production. The low productivity of cotton is ascribed to many factors, but the most serious is the intensity of insect pest damage. The insect pest's spectrum of cotton is quite complex and as many as 1326 species of insect pests have been listed on this crop throughout the world (Agarwal et al., 1984). Cotton is subjected to damage by 162 species of pests right from germination to the final picking (Dhaliwal and Arora, 1998).

Cotton aphids are the most serious pests of cotton all over the world (Rummel et al., 1995). Cotton aphids injure cotton plants by continually feeding on fluids in plant phloem tubes. This feeding can stimulate foliar alterations, delay of the plant growth, fewer fruit setting, lower fruit retention and reduced cotton lint weight (Raboudi et al., 2002). In addition, virus transmission can lessen the 
cotton yield up to $30-40 \%$. Cotton aphids reduced leaf area by $58 \%$ and shoot biomass by $45 \%$ (Muhammad et al., 2014).

During 2006, the mealy bug, Phenacoccus solenopsis caused economic damage, reducing yields by up to 40-50 percent in infested fields in several parts of Gujarat (Nagrare et al., 2009). At around the same time, mealy bug infestations were found in all the nine cotton growing states. The mealy bug has become a major pest in almost all cotton growing states of India. Apart from yield losses, the cost of insecticide application has increased by US \$ 250-375 per acre in both India (Nagrare et al., 2009).

Nanotechnology is an interdisciplinary science with a wide array of applications in various fields like medicine, information and communication, chemistry, environment, defence, security, consumer goods and agriculture.

Application of nanotechnology in crop protection holds a significant promise in management of insects and pathogens, by controlled and targeted delivery of agrochemicals and also by providing diagnostic tools for early detection. So the present investigation was carried out on synthesis of green silica nanoparticles and their effect on cotton aphid and mealybug.

\section{Materials and Methods}

The rice husk (variety, BPT-5204) was collected from the Shree Lakshmi Narayana Rice Mill, Manchalapur Road, Raichur, Karnataka, India. Cotton seeds were collected from Main Agricultural Research Station (MARS) UAS campus, Raichur. The chemicals and metal nanoparticles were procured from M/s. High Media, Bangalore and M/s. Sigma Aldrich, Bangalore for conducting the experiment.

\section{Biosynthesis of silica nanoparticles from rice husk}

Rice husk was washed thoroughly with potable water then dried in a hot air oven at $110{ }^{\circ} \mathrm{C}$ for $24 \mathrm{~h}$. The dried rice husk was refluxed with an acidic solution of $1 \mathrm{~N} \mathrm{HCl}$ at $85^{\circ} \mathrm{C}$ for $90 \mathrm{~min}$. Then sample was cooled at room temperature and thoroughly washed with warm distilled water until the rinse became free from acid. The refluxed husk was dried in hot air oven at $110{ }^{\circ} \mathrm{C}$ for $24 \mathrm{~h}$ and then subjected to heat treatment in muffle furnace at $7000{ }^{\circ} \mathrm{C}$ for $2 \mathrm{~h}$ to obtain the ash. Later $20 \mathrm{~g}$ of ash was stirred in a $160 \mathrm{ml}$ of $2.5 \mathrm{M} \mathrm{NaOH}$ solution and solution was heated in a covered beaker at $90{ }^{\circ} \mathrm{C}$ for $3 \mathrm{~h}$ by stirring constantly and filtered through filter paper (Whatman No.4). Then the solution was allowed to cool at room temperature and $10 \mathrm{M} \mathrm{H}_{2} \mathrm{SO}_{4}$ was then added under constant stirring at controlled conditions until it reached to $\mathrm{pH} 2$, then $\mathrm{NH}_{4} \mathrm{OH}$ was used to adjust $\mathrm{pH}$ level up to 8.5 and was allowed to stand at room temperature for $3 \mathrm{~h}$. White silica precipitate was washed repeatedly with the distilled water until the filtrate was completely free from alkali. The silica was dried in hot air oven at $105^{\circ} \mathrm{C}$ temperature for $24 \mathrm{~h}$.

Silica nanoparticles were prepared by using refluxing technique of the above extracted silica with $6 \mathrm{M}$ of hydrochloric acid $(\mathrm{HCl})$ at $85^{\circ} \mathrm{C}$ for $4 \mathrm{~h}$ and washed repeatedly using distilled water to make it acid free. Then it was dissolved in $2.5 \mathrm{M}$ sodium hydroxide $(\mathrm{NaOH})$ by continuous stirring and sulphuric acid $\left(\mathrm{H}_{2} \mathrm{SO}_{4}\right)$ was added until it reached to $\mathrm{pH}$ 8. The precipitated silica was washed repeatedly with warm distilled water to make it alkali free and then dried in the hot air oven at $50{ }^{\circ} \mathrm{C}$ for $48 \mathrm{~h}$ (Rafiee et al., 2012) and finally obtained the silica powder. Later characterization was carried out by zetasizer, UV-visible spectroscopy, X-ray diffraction and scanning electron microscope. 


\section{Bioassay studies on aphid and mealybug}

The aphid nymphs required for the experiment was sourced from the insect culture maintained in the laboratory of Department of Agricultural Entomology. For bioassay studies the cotton leaves were placed in petri plates as food. Then ten nymphs of aphids were released on each petri plate. Later different concentrations $(250,500,1000,1500$ and $2000 \mathrm{ppm}$ ) of silica nanoparticles were sprayed using potters tower sprayer and observations were recorded on mortality at 1 , 3 and 5 days interval. It was compared with metal based nanoparticles and dinotefuron $20 \% \mathrm{SG}$ at $0.3 \mathrm{~g} / \mathrm{L}$ as chemical check. It was replicated thrice.

Similarly, for mealybug, cotton leaves were treated with silica nanoparticles and nymphs were released. Later mortality was recorded at 1,3 and 5 days interval. It was compared with metal based nanoparticles and buprofezin 25 $\mathrm{SC}$ at $1 \mathrm{ml} / \mathrm{L}$ as chemical check. It was replicated thrice.

Turgidity of leaf was maintained by placing cotton stubs below the leaf in petri plate and petiole of the leaf was covered with cotton dipped in agar solution.

Per cent mortality of nymphs was calculated by using the formula.

Per cent nymphal mortality $=\frac{\text { Number of dead insects }}{\text { Total number of insects }} \times 100$

\section{Results and Discussion}

Biosynthesis of silica nanoparticles from rice husk

The characterization of biosynthesized silica nanoparticles for identification of its size, morphology and functional group are explained below.
The results of zetasizer revealed that average particle diameter of silica nanoparticles was $26.19 \mathrm{~nm}$ (Fig. 1). Results are in line with the findings of Das et al., (2014).

The UV-Visible spectrum of SNPs recorded maximum absorption band edge of $310 \mathrm{~nm}$ in 1.95 absorbance (Fig. 2). These optical features are similar to those obtained in previous reports and attributed to $\mathrm{Si}-\mathrm{O}-\mathrm{Si}$ bond confirming the presence of silica nanoparticles (Vaccaro et al., 2013; Djangang et al., 2015).

The X-ray diffraction pattern of silica nanoparticles which is characterized by a broad halo band of absorbance at about $2 \theta=15-25^{\circ}$ region which confirms the amorphous structure of the biosynthesized silica nanoparticles (Fig. 3).

Similar results were recorded by Djangang et al., (2015) who reported amorphous nature of silica nanoparticles from rice husk.

SEM analysis data showed that uniformly distributed silica nanoparticles were in the agglomerated form with spherical shape (Plate 1). Results are in accordance with findings of Vaccaro et al., (2013) Djangang et al., (2015).

\section{Mortality of aphids caused by silica nanoparticles}

At one day after treatment, the mortality of aphids ranged between 30.00 to 56.67 per cent among different treatments (Table 1). The metal Si nanoparticle @ 2000 ppm $\left(\mathrm{T}_{10}\right)$ recorded highest mortality $(56.67 \%)$ and was significantly superior to all other treatments.

The next highest mortality of 53.33 per cent was observed in metal Si nanoparticle @ 1500 ppm $\left(\mathrm{T}_{8}\right)$ and green Si nanoparticle @ 2000 ppm $\left(T_{9}\right)$ which were on par with each other (Fig. 4). 
At three days after treatment, cent per cent mortality was observed in chemical check dinotefuran@0.3 g/l $\left(\mathrm{T}_{11}\right)$ which proved to be significantly superior to all other treatments (Table 1). This was followed by 83.33 per cent mortality in metal Si nanoparticle @ 2000 ppm $\left(\mathrm{T}_{10}\right)$ treatment. The metal $\mathrm{Si}$ nanoparticle @ 1500 ppm $\left(\mathrm{T}_{8}\right)$ and green Si nanoparticle@2000 ppm $\left(\mathrm{T}_{9}\right)$ recorded 73.33 per cent mortality. Untreated control recorded the lowest mortality of 3.33 per cent (Fig. 4).
At five days after treatment mortality of aphids ranged from 6.67 to 100.00 per cent among various treatments (Table 1).

The green Si nanoparticle @ 2000 ppm $\left(\mathrm{T}_{9}\right)$, metal Si nanoparticle @ 2000 ppm $\left(\mathrm{T}_{10}\right)$ and dinotefuran@0.3 g/l $\left(\mathrm{T}_{11}\right)$ recorded cent per cent mortality.

Lowest mortality was recorded in untreated control with 6.67 per cent (Fig. 4).

Table.1 Effect of silica nanoparticles on cotton aphid, Aphis gossypii

\begin{tabular}{|c|c|c|c|c|}
\hline \multirow[t]{2}{*}{ Treatment details } & \multirow[t]{2}{*}{ Dosage } & \multicolumn{3}{|c|}{$\begin{array}{l}\text { Per cent mortality of aphids at different } \\
\text { intervals }\end{array}$} \\
\hline & & 1 DAT & 3 DAT & 5 DAT \\
\hline $\mathrm{T}_{1}$ : Green Si nanoparticle & $250 \mathrm{ppm}$ & $\begin{array}{c}30.00 \\
(33.21)^{\mathrm{g}_{*}}\end{array}$ & $\begin{array}{c}46.67 \\
(43.09)^{\mathrm{h}}\end{array}$ & $\begin{array}{c}63.33 \\
(52.73)^{\mathrm{h}}\end{array}$ \\
\hline $\mathrm{T}_{2}:$ Metal Si nanoparticle & $250 \mathrm{ppm}$ & $\begin{array}{c}36.67 \\
(37.27)^{\mathrm{f}}\end{array}$ & $\begin{array}{c}53.33 \\
(46.91)^{\mathrm{g}}\end{array}$ & $\begin{array}{c}70.00 \\
(56.79)^{\mathrm{g}}\end{array}$ \\
\hline $\mathrm{T}_{3}$ : Green Si nanoparticle & $500 \mathrm{ppm}$ & $\begin{array}{c}36.67 \\
(37.27)^{\mathrm{f}}\end{array}$ & $\begin{array}{c}53.33 \\
(46.91)^{\mathrm{g}}\end{array}$ & $\begin{array}{c}73.33 \\
(58.91)^{f}\end{array}$ \\
\hline $\mathrm{T}_{4}:$ Metal Si nanoparticle & $500 \mathrm{ppm}$ & $\begin{array}{c}43.33 \\
(41.17)^{\mathrm{e}}\end{array}$ & $\begin{array}{c}56.67 \\
(48.83)^{\mathrm{f}}\end{array}$ & $\begin{array}{c}76.67 \\
(61.12)^{\mathrm{e}}\end{array}$ \\
\hline $\mathbf{T}_{5}$ : Green Si nanoparticle & $1000 \mathrm{ppm}$ & $\begin{array}{c}43.33 \\
(41.17)^{\mathrm{e}}\end{array}$ & $\begin{array}{c}60.00 \\
(50.77)^{\mathrm{e}}\end{array}$ & $\begin{array}{c}76.67 \\
(61.12)^{\mathrm{e}}\end{array}$ \\
\hline $\mathrm{T}_{6}:$ Metal Si nanoparticle & $1000 \mathrm{ppm}$ & $\begin{array}{c}50.00 \\
(45.00)^{\mathrm{c}}\end{array}$ & $\begin{array}{c}66.67 \\
(54.74)^{d}\end{array}$ & $\begin{array}{c}83.33 \\
(65.91)^{\mathrm{d}}\end{array}$ \\
\hline $\mathrm{T}_{7}$ : Green Si nanoparticle & $1500 \mathrm{ppm}$ & $\begin{array}{c}46.67 \\
(43.09)^{d}\end{array}$ & $\begin{array}{c}66.67 \\
(54.74)^{d}\end{array}$ & $\begin{array}{c}90.00 \\
(71.57)^{c}\end{array}$ \\
\hline $\mathrm{T}_{8}:$ Metal Si nanoparticle & $1500 \mathrm{ppm}$ & $\begin{array}{c}53.33 \\
(46.91)^{b}\end{array}$ & $\begin{array}{c}73.33 \\
(58.91)^{\mathrm{c}}\end{array}$ & $\begin{array}{c}96.67 \\
(79.48)^{b}\end{array}$ \\
\hline $\mathrm{T}_{9}$ : Green Si nanoparticle & $2000 \mathrm{ppm}$ & $\begin{array}{c}53.33 \\
(46.91)^{b}\end{array}$ & $\begin{array}{c}73.33 \\
(58.91)^{\mathrm{c}}\end{array}$ & $\begin{array}{c}100.00 \\
(90.00)^{\mathrm{a}}\end{array}$ \\
\hline $\mathrm{T}_{10}$ : Metal Si nanoparticle & $2000 \mathrm{ppm}$ & $\begin{array}{c}56.67 \\
(48.83)^{\mathrm{a}}\end{array}$ & $\begin{array}{c}83.33 \\
(65.91)^{b}\end{array}$ & $\begin{array}{c}100.00 \\
(90.00)^{\mathrm{a}}\end{array}$ \\
\hline $\mathrm{T}_{11}$ : Dinotefuran $20 \% \mathrm{SG}$ & $0.30 \mathrm{~g} / \mathrm{l}$ & $\begin{array}{c}46.67 \\
(43.09)^{\mathrm{d}}\end{array}$ & $\begin{array}{c}100.00 \\
(90.00)^{\mathrm{a}}\end{array}$ & $\begin{array}{c}100.00 \\
(90.00)^{\mathrm{a}}\end{array}$ \\
\hline $\mathrm{T}_{12:}$ Untreated control & -- & $\begin{array}{c}0.00 \\
(0.00)^{h}\end{array}$ & $\begin{array}{c}3.33 \\
(10.52)^{\mathrm{i}}\end{array}$ & $\begin{array}{c}6.67 \\
(14.96)^{i}\end{array}$ \\
\hline S.Em & & 0.16 & 0.21 & 0.15 \\
\hline CD@1\% & & 0.62 & 0.82 & 0.59 \\
\hline
\end{tabular}

$\mathrm{n}=30$ second instar nymphs

DAT- Days after treatment

*Figures in the parentheses are "arcsine" transformed values

Means followed by same letters in a column are not significantly different $(\mathrm{P}=0.01)$ by DMRT 
Table.2 Effect of silica nanoparticles on cotton mealybug, Phenacoccus solenopsis

\begin{tabular}{|c|c|c|c|c|}
\hline \multirow[t]{2}{*}{ Treatment details } & \multirow[t]{2}{*}{ Dosage } & \multicolumn{3}{|c|}{$\begin{array}{l}\text { Per cent mortality of mealybugs at different } \\
\text { intervals }\end{array}$} \\
\hline & & $1 \mathrm{DAT}$ & 3 DAT & 5 DAT \\
\hline$T_{1}$ : Green Si nanoparticle & $250 \mathrm{ppm}$ & $23.33(28.88)^{\mathrm{h}_{*}}$ & $40.00(39.23)^{\mathrm{j}}$ & $50.00(45.00)^{\mathrm{g}}$ \\
\hline $\mathrm{T}_{2}$ : Metal Si nanoparticle & $250 \mathrm{ppm}$ & $30.00(33.21)^{\mathrm{g}}$ & $43.33(41.17)^{\mathrm{i}}$ & $56.67(48.83)^{\mathrm{f}}$ \\
\hline $\mathrm{T}_{3}$ : Green Si nanoparticle & 500 ppm & $33.33(35.26)^{\mathrm{t}}$ & $50.00(45.00)^{\mathrm{h}}$ & $56.67(48.83)^{\mathrm{t}}$ \\
\hline $\mathrm{T}_{4}$ : Metal Si nanoparticle & $500 \mathrm{ppm}$ & $36.67(37.27)^{\mathrm{e}}$ & $50.00(45.00)^{\mathrm{h}}$ & $63.33(52.73)^{\mathrm{e}}$ \\
\hline$T_{5}$ : Green Si nanoparticle & $1000 \mathrm{ppm}$ & $36.67(37.27)^{\mathrm{e}}$ & $53.33(46.91)^{\mathrm{g}}$ & $70.00(56.79)^{\mathrm{d}}$ \\
\hline $\mathrm{T}_{6}:$ Metal Si nanoparticle & $1000 \mathrm{ppm}$ & $43.33(41.17)^{\mathrm{d}}$ & $56.67(48.83)^{\mathrm{f}}$ & $83.33(65.91)^{\mathrm{c}}$ \\
\hline$T_{7}:$ Green Si nanoparticle & $1500 \mathrm{ppm}$ & $46.67(43.09)^{\mathrm{c}}$ & $60.00(50.77)^{\mathrm{e}}$ & $83.33(65.91)^{\mathrm{c}}$ \\
\hline $\mathrm{T}_{8}$ : Metal Si nanoparticle & $1500 \mathrm{ppm}$ & $46.67(43.09)^{\mathrm{c}}$ & $63.33(52.73)^{\mathrm{d}}$ & $90.00(71.57)^{b}$ \\
\hline$T_{9}$ : Green Si nanoparticle & $2000 \mathrm{ppm}$ & $50.00(45.00)^{\mathrm{b}}$ & $66.67(54.74)^{\mathrm{c}}$ & $100.00(90.00)^{\mathrm{a}}$ \\
\hline $\mathrm{T}_{10}$ : Metal Si nanoparticle & $2000 \mathrm{ppm}$ & $53.33(46.91)^{\mathrm{a}}$ & $73.33(58.91)^{b}$ & $100.00(90.00)^{\mathrm{a}}$ \\
\hline $\mathrm{T}_{11}$ : Buprofezin $25 \mathrm{SC}$ & $1.00 \mathrm{ml} / 1$ & $46.67(43.09)^{\mathrm{c}}$ & $83.33(65.91)^{\mathrm{a}}$ & $100.00(90.00)^{\mathrm{a}}$ \\
\hline $\mathrm{T}_{12:}$ Untreated control & -- & $0.00(0.00)^{\mathrm{i}}$ & $0.00(0.00)^{\mathrm{k}}$ & $3.33(10.52)^{\mathrm{h}}$ \\
\hline S.Em & & 0.19 & 0.15 & 0.19 \\
\hline CD@1\% & & 0.77 & 0.61 & 0.77 \\
\hline
\end{tabular}

$\mathrm{n}=30$ second instar nymphs

DAT- Days after treatment

*Figures in the parentheses are "arcsine" transformed values

Means followed by same letters in a column are not significantly different $(\mathrm{P}=0.01)$ by DMRT

Fig.1 Average particle diameter of green silica nanoparticles

$\begin{array}{rlllll}\text { Results } & & & & \\ \text { Z-Average (d.nm): } & 26.19 & \text { Peak 1: } & 35.49 & 85.2 & 14.01 \\ \text { Pdl: } & 0.362 & \text { Peak 2: } & 6.713 & 9.6 & 1.264 \\ \text { Intercept: } & 0.763 & \text { Peak 3: } & 4209 & 5.2 & 1000 \\ \text { Result quality } & \text { Refer to quality report } & & & \end{array}$

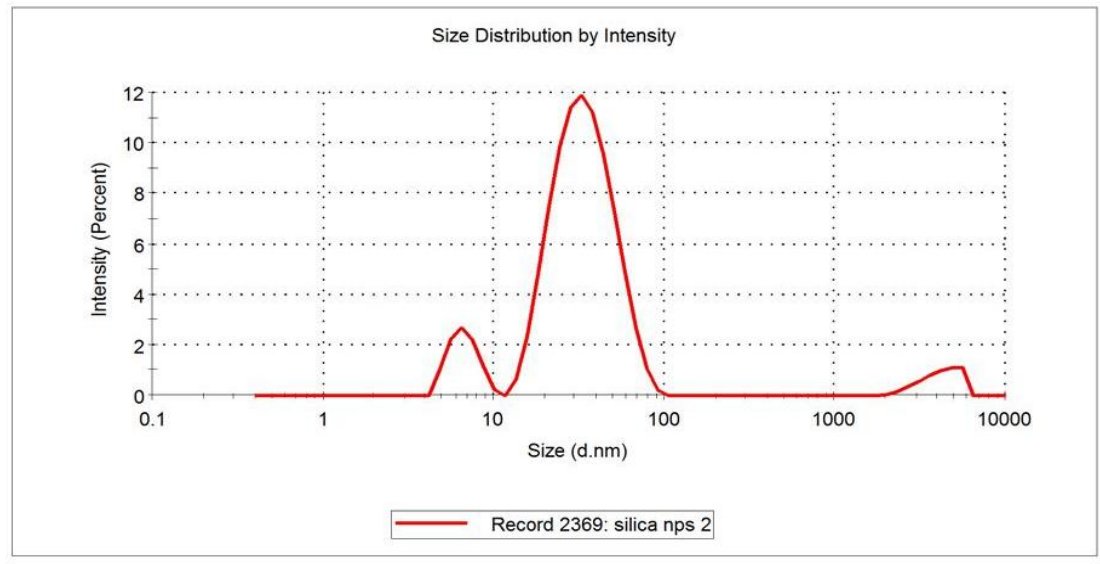


Fig.2 UV - Visible spectrum analysis of green silica nanoparticles

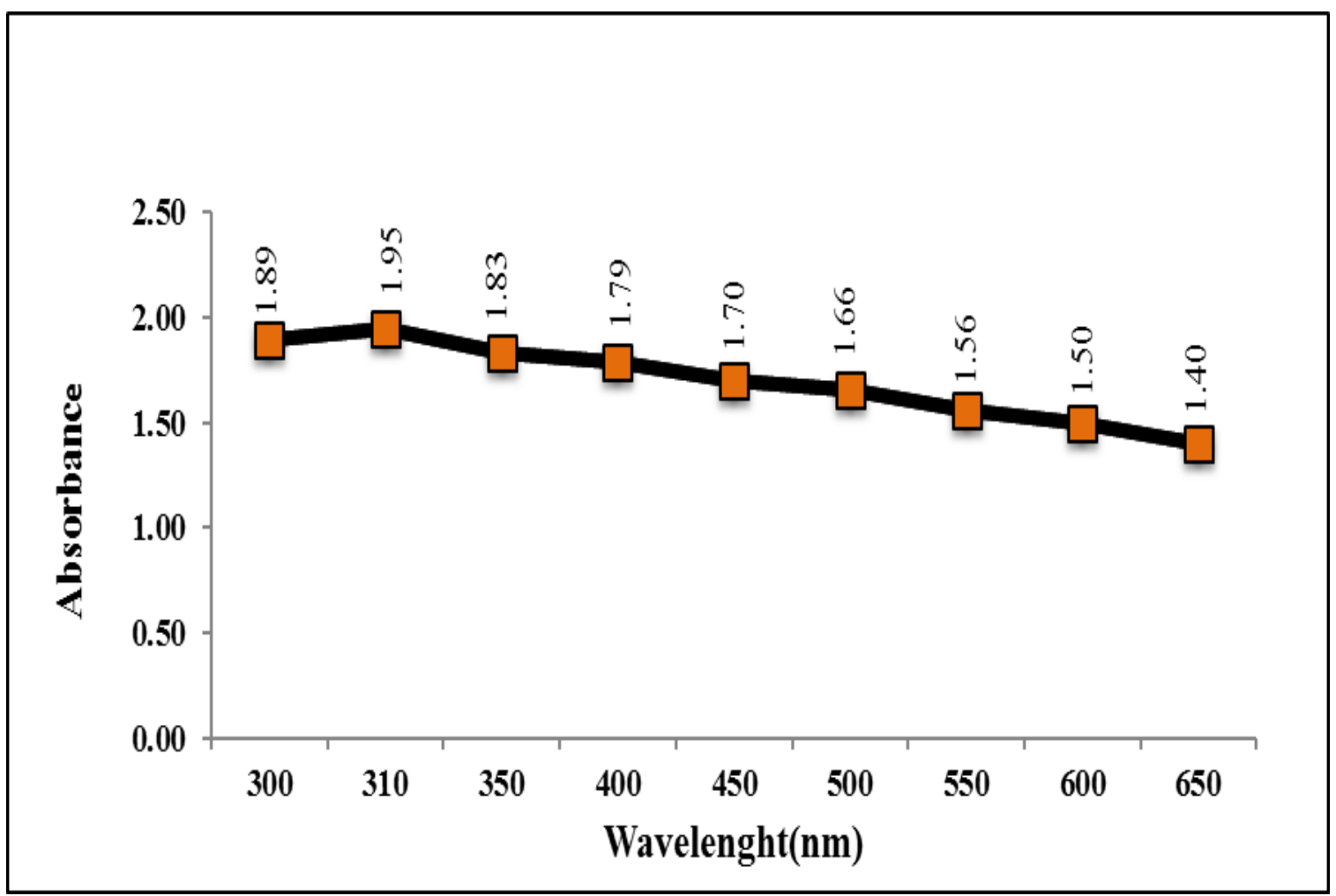

Fig.3 X- ray diffraction of green silica nanoparticles

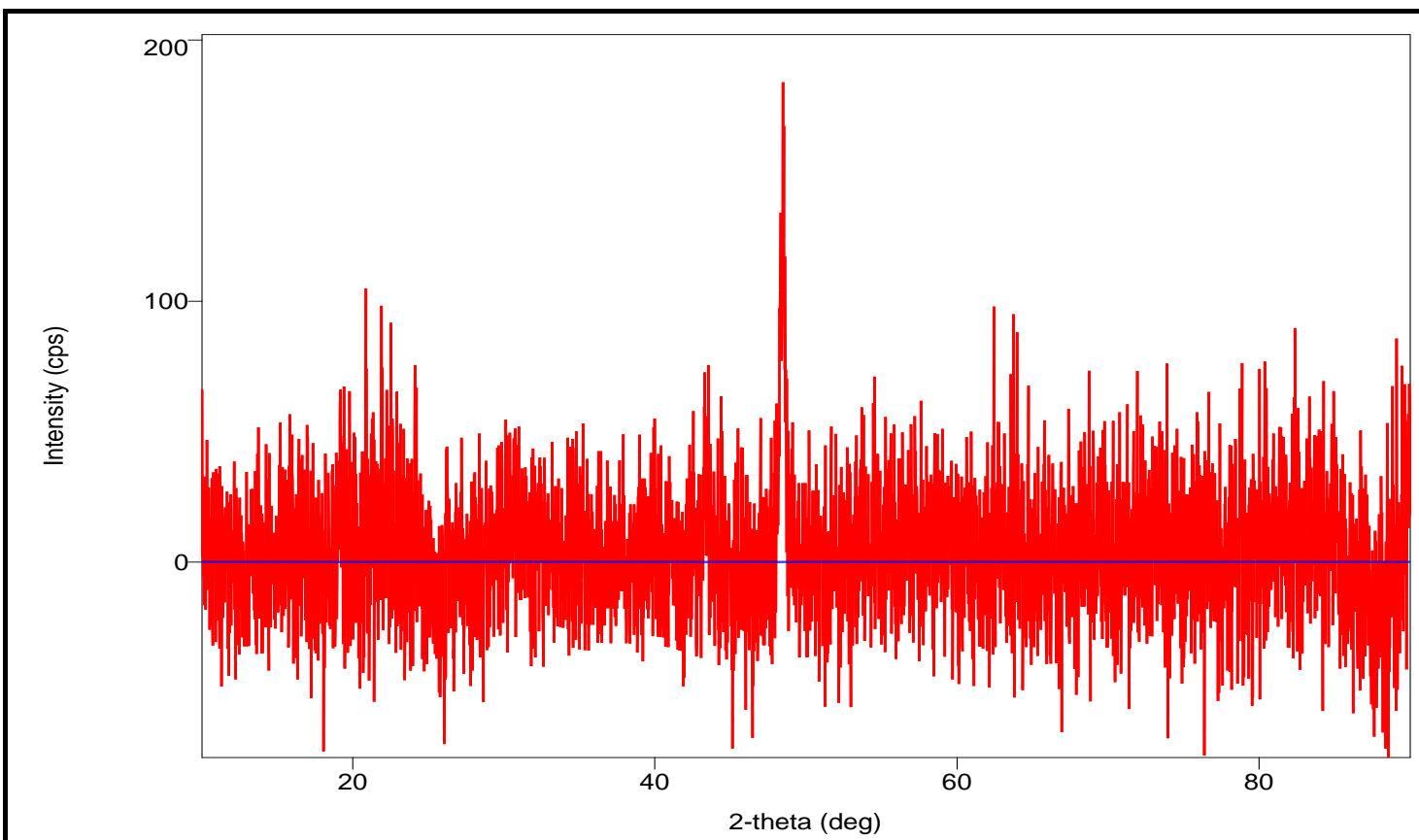


Fig.4 Mortality of cotton aphid, Aphis gossypii caused by silica nanoparticles

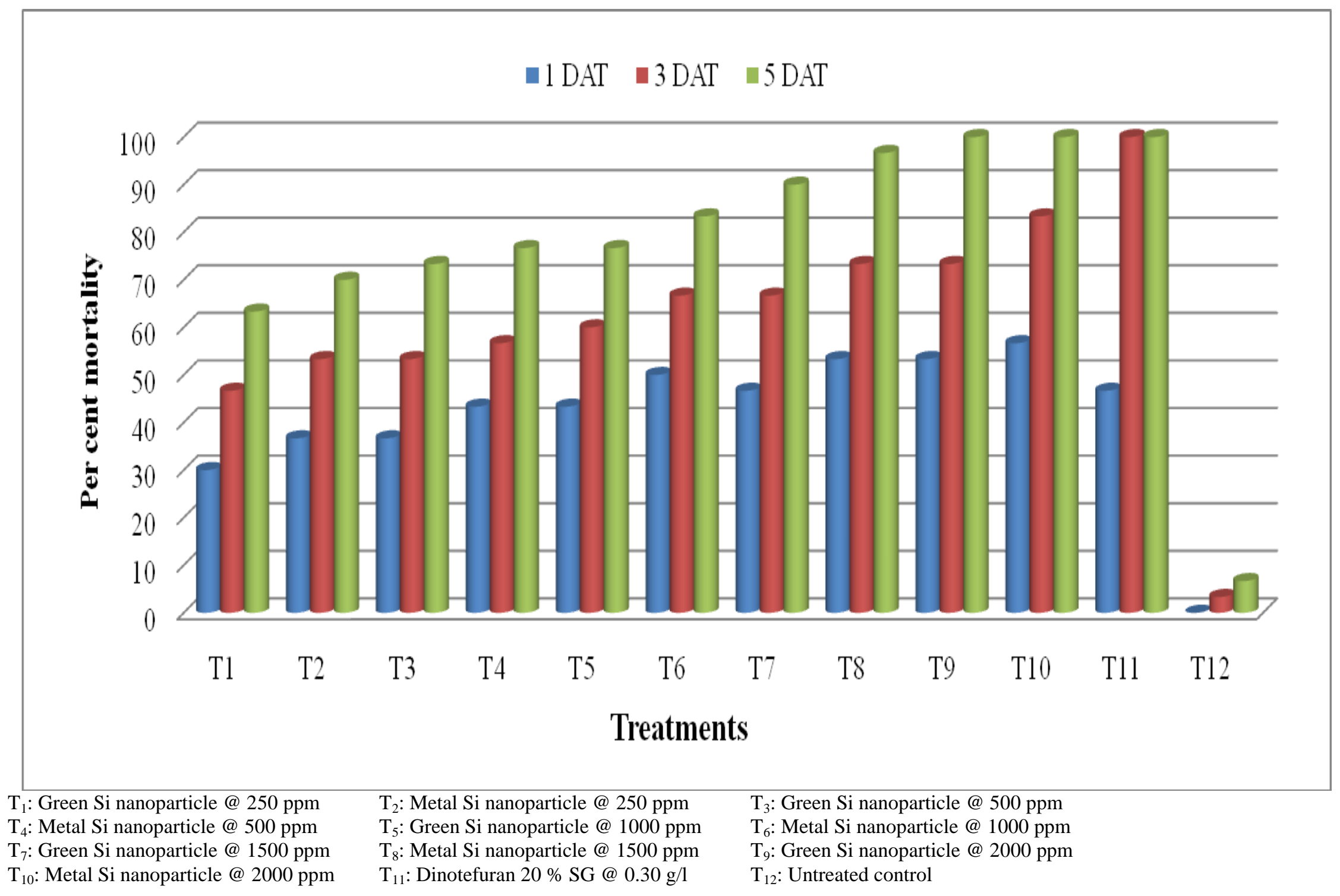


Fig.5 Mortality of cotton mealybug, Phenacoccus solenopsis caused by silica nanoparticles

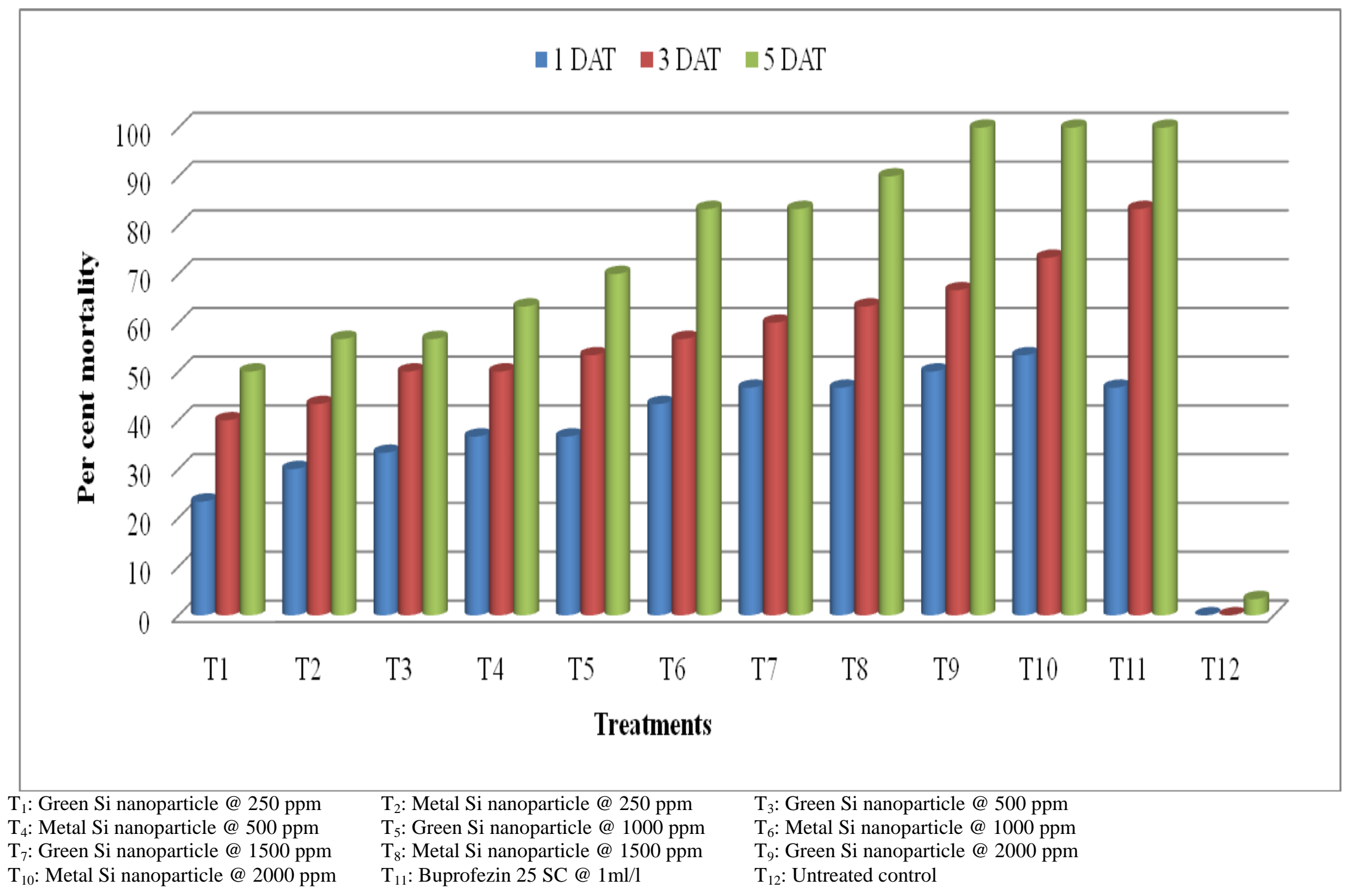


Plate.1 Scanning electron microscope image of green silica nanoparticles

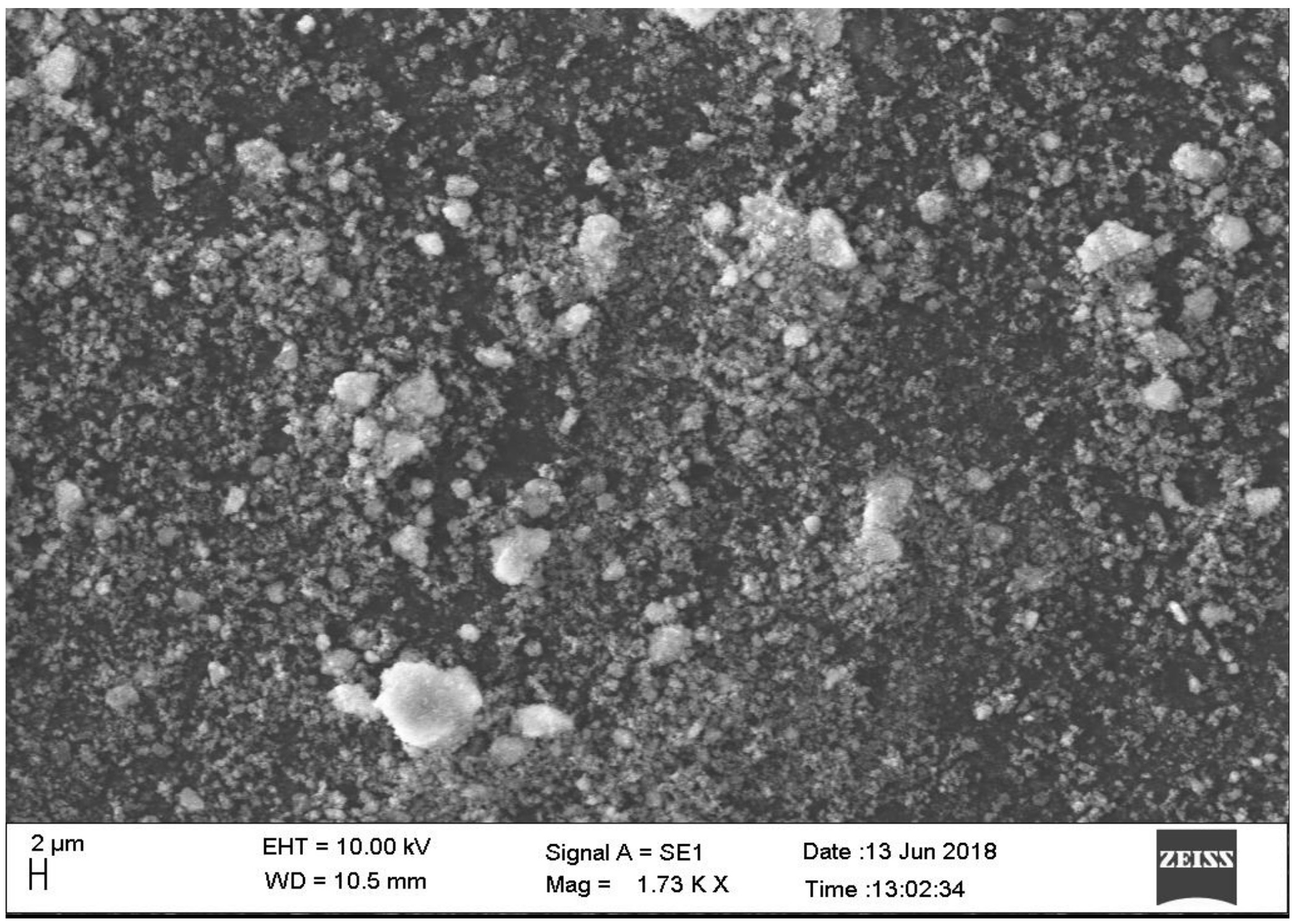


Nearer to present findings Abd El-Wahab et al., (2016) reported a lower dose of $500 \mathrm{ppm}$ of hydrophilic nano silica could be an effective pest control approach for species Myzus persicae, Acyrthosiphon pisum and Aphis craccivora. Finally, it could be concluded that silica had moderate control affect against tested aphid species. In line with present findings Rouhani et al., 2012, Nitai et al., 2010 and Lee et al., 2005 found that silica accumulates intracellular in plants and prevent sucking.

\section{Mortality of mealybugs caused by silica nanoparticles}

At one day after treatment mortality of mealybugs ranged from 23.33 to 53.33 per cent (Table 2). Highest mortality of 53.33 per cent was recorded in metal Si nanoparticle @ 2000 ppm $\left(\mathrm{T}_{10}\right)$ and it was significantly superior to all other treatments. The next best treatment was green Si nanoparticle @ 2000 ppm $\left(\mathrm{T}_{9}\right)$ with 50.00 per cent mortality. There was no mortality of mealybugs in untreated control. The lowest mortality of 23.33 per cent was recorded in green Si nanoparticle @ 250 ppm $\left(\mathrm{T}_{1}\right)$ treatment (Fig. 5).

At three days after treatment, the mortality rates increased proportionately with increased concentration in all treatments (Table 2). Chemical check buprofezin 25 SC @ 1 ml/1 $\left(\mathrm{T}_{11}\right)$ recorded the highest mortality of 83.33 per cent and was significantly superior to all other treatments. This was followed by metal $\mathrm{Si}$ nanoparticle and green Si nanoparticle @ 2000 ppm with 73.33 and 66.67 per cent mortality respectively (Fig. 5).

At five days after treatment, the mortality ranged from 50.00 to 100.00 per cent (Table 2) of which green Si nanoparticle @ 2000 ppm $\left(\mathrm{T}_{9}\right)$, metal Si nanoparticle @ 2000 ppm $\left(\mathrm{T}_{10}\right)$ and buprofezin $25 \mathrm{SC} @ 1 \mathrm{ml} / \mathrm{l}\left(\mathrm{T}_{11}\right)$ recorded cent per cent mortality. Next highest mortality was exhibited in metal Si nanoparticle @ 1500 ppm $\left(\mathrm{T}_{8}\right)$ with 90.00 per cent. Lowest mortality was witnessed in untreated control with 3.33 per cent (Fig. 5).
Since there are no reviews available on silica nanoparticles against mortality of cotton mealybug, hence reviews of effect of silica green nanoparticles on other insects are discussed here. Rouhani et al., (2013) reported that nanosilica and nanosilver on Callosobruchus maculatus F. resulted in 100 and 75 per cent mortality at the highest concentration of $2.5 \mathrm{~g} \mathrm{~kg}^{-1}$ on day 14 . Ziaee and Ganji (2016) reported the highest insecticidal potential of silica nanoparticles could be attributed due to increase in high surface to volume ratio which increased insect contact with particles which led to more cuticle desiccation and death.

The green silica nanoparticle @ 2000 ppm has effectively managed both the sucking pests like cotton aphid and mealybug. Results suggest the possibility of using green silica nanoparticles to eradicate pests and can be used as valuable tools in pest management. While the environmental effects of using silica nanoparticles as insecticide is subject of further study, one obvious advantage of using them as insecticides is the low risk of developing resistance by the insects in long term uses.

\section{References}

Abd El-Wahab, A. S., El-Bendary, H. M. and El-Helaly, A. A., 2016, Nano silica as a promising nano pesticide to control three different aphid species under semi-field conditions in Egypt. Egypt. Acad. J. Biolog. Sci., 8(2): 35-49.

Agarwal, R. A., Gupta, G. P. and Garg, D. O., 1984, Cotton pest management in India. Research Publication, Azad nagar, Delhi, pp. 1-9.

Das, D., Yang, Y., Brien, J. S. O., Breznan, D., Nimesh, S., Bernatchez, S., Hill, M., Sayari, A., Vincent, R. and Kumarathasan, P., 2014, Synthesis and physicochemical characterization of mesoporous $\mathrm{SiO}_{2}$ nanoparticles. $J$. Nanomater., 62(6): 11-12. 
Dhaliwal and Arora, 1998, Principles of insect pest management. Kalyani publishers, Ludhiana, Punjab, India, p. 297.

Djangang, C, N., Mlowe, S., Njopwouo, D. and Revaprasadu, N., 2015, One-step synthesis of silica nanoparticles by thermolysis of rice husk ash using nontoxic chemicals ethanol and polyethylene glycol. J. Appl. Chem., 4(4): 1218-1226.

Lee, K., Chung, S. J. and Kim, H. K., 2005, Effectiveness of Bionatrol on the control of two spotted spider mite (Tetranychus urticae), Aphid (Aphis gossypii) and Whitefly (Trialeurodes vaporariorum) on greenhouse cucumber (Cucumis spp, KASA). J. Korean Soc. Horti. Sci., 46: 241-245.

Muhammad, K. S., Iqra, A., Nadia, I., Waheed, I., Aqsad, R., Fakhra, A., Kiran, A. and Rafaqat, A., 2014, Cotton aphid Aphis gossypii (Homoptera: Aphididae) a challenging pest; biology and control strategies: a review. Int. J. Appl. Biol. Pharm. Technol., 5: 228-294.

Nagrare, V. S., Kranthi, S., Biradar, V. K., Zade, N. N., Sangode, V., Kakde, G., Shukla, R. M., Shivare, D., Khadi, B. M. and Kranthi, K. R., 2009, Widespread infestation of the exotic mealybug species Phenacoccus solenopsis (Tinsley) (Hemiptera: Pseudococcidae) on cotton in India. Bull. Entomol. Res., 99: 537-41.

Nitai, D., Sumistha, D., Brahmacharya, R. L., Chandrab, R., Sandeep, S. and Arunava, G., 2010, Entomotoxicity assay of silica, zinc oxide, titanium dioxide, aluminium oxide nanoparticles on Lipaphis pseudobrassicae. AIP Conf. Proc., 1276: 302. http://dx.doi.org/ $10.1063 / 1.3504315$.
Raboudi, F., Ben Moussa, A., Makni, H., Marraakchi, M. and Makni, M., 2002, Serological detection of plant viruses and host plant in Tunisia. EPPO Bull., 32: 495-98.

Rafiee, E., Shahebrahimi, S., Feyzi, M. and Shaterzadeh, M., 2012, Optimization and characterization of nanosilica produced from rice husk (common waste material). Int. Nano. Lett., 2(29): 1-8.

Rouhani, M., Samih, M. A. and Kalantari, S., 2012, Insecticide effect of silver and zinc nanoparticles against Aphis nerii (Boyer De Fonscolombe) (Hemiptera: Aphididae). Chilean J. Agric. Res., 72(4): 80-95.

Rouhani, M., Samih, M. A. and Kalantari, S., 2013, Insecticidal effect of silica and silver nanoparticles on the cowpea seed beetle, Callosobruchus maculatus F. (Coleoptera: Bruchidae). J. Entomol. Res., 4: 297-305.

Rummel, D. R., Amold, M. D., Slosser, J. E., Neece, K. C. and Pinchak, W. E., 1995, Cultural factors influencing the abundance of Aphis gossypii Glover in texas high plains cotton. Southwest. Entomol., 20: 396-406.

Vaccaro, L., Spallino, L., Agnello, S., Buscarino, G. and Cannas, M., 2013, Defect- related visible luminescence of silica nanoparticles. Phys. Status. Solidi. C., 10(4): 658-661.

Ziaee, M. and Ganji, Z., 2016, Insecticidal efficacy of silica nanoparticles against Rhyzopertha dominica F. and Tribolium confusum Jacquelin du Val. J. Pl. Prot. Res., 56(3): 251-255.

\section{How to cite this article:}

Pavitra, G., N. Sushila, A.G. Sreenivas, J. Ashok and Sharanagouda, H. 2018. Biosynthesis of Green Silica Nanoparticles and Its Effect on Cotton Aphid, Aphis gossypii Glover and Mealybug, Phenacoccus solenopsis Tinsley. Int.J.Curr.Microbiol.App.Sci. 7(10): 1450-1460. doi: https://doi.org/10.20546/ijcmas.2018.710.162 